\title{
Development of the gonadotrophic and somatotrophic axes of sheep
}

\author{
J. Polkowska \\ The Kielanozoski Institute of Animal Physiology and Nutrition, Polish Academy of Sciences, \\ 05-110 Jabłonna, Poland
}

The hypothalamo-pituitary-gonadotrophic axis develops in the sheep fetus from midgestation to late gestation. The GnRH neuronal centres seem to be fully developed in the fetus and their localization complies with the adult pattern. Pituitary gonadotrophs are responsive to exogenous $\mathrm{GnRH}$ and release $\mathrm{LH}$ and FSH in a pulsatile fashion; the highest concentrations in plasma are found during late gestation. In sheep, maturational changes of this axis continue through to the prepubertal period. The GnRH neuronal system is established at about 12 weeks of age. The pattern of LH and FSH release is characteristic for each gonadotrophin depending on age and sex. The responsiveness of the gonadotrophs to GnRH increases up to 3 weeks of age. It is concluded that the changes in morphology and physiology of the hypothalamo-pituitary-gonadotrophic axis reflect the progressive maturation of the central mechanisms involved in the control of gonadotrophin secretion throughout fetal and prepubertal growth in sheep. Development of the hypothalamo-pituitary-somatotrophic axis begins in the fetus around midgestation. The central regulation of growth hormone $(\mathrm{GH})$ in the fetus probably has a dual character, although the growth hormone releasing hormone (GHRH) neuronal system has not yet been observed in sheep. The somatostatin neuronal system develops in diverse neuronal centres in the fetus. The somatostatin centre involved in hypophysiotrophic functions does not develop fully before birth and is established over the first 10 weeks after birth. Plasma GH concentrations are very high in the fetus and fall suddenly in the perinatal period, and after a temporary increase they decline with age. Fetal somatotrophs are highly sensitive to exogenous GHRH but their sensitivity to exogenous somatostatin is much lower in the pre- than in the postnatal period. It appears that central regulation of $\mathrm{GH}$ secretion is not fully established in the sheep fetus. The importance of somatostatin as a hypophysiotrophic hormone increases with age of the sheep.

\section{Introduction}

Regulatory systems in the hypothalamo-pituitary unit are established gradually through a sequence of morphological and physiological changes beginning in fetal life and ending in adulthood. This review deals with recent data describing the endocrinology, morphology, physiology and possible central regulation of pre- and postnatal hypothalamo-pituitary axes involved in reproduction and growth of sheep. The development of these axes is a complex process involving central as well as peripheral regulatory mechanisms and leads to somatic and sexual maturity of the organism (Ojeda et al., 1980). There is some evidence that the hypothalamo-pituitary axis in mammals is functional from early stages of fetal life (reviewed from Sklar et al., 1981). In the sheep fetus, morphological maturation of the median eminence has been observed as early as days $48-67$ of gestation (Matwijiw et al., 1989). The vascular 
link between the hypothalamus and pituitary is established in the early stages of gestation suggesting that in the sheep fetus, hypothalamic releasing factors can be transported directly via the portal vascular system to the pituitary gland to exert their stimulatory or inhibitory actions. However, the physiological roles of some of the neuropeptides found in the embryo are not fully established. In addition to their functions in adults, they might be involved in other processes such as histogenesis, cell division, or the formation and migration of neurones (Lauder, 1983). The individual components of the endocrine axes probably start their embryonic development independently of each other and interactions between them are established only in the last stage of their maturation (Huthaniemi and Warren, 1990).

\section{Hypothalamo-Pituitary-Gonadal Axis}

\section{Prenatal period}

In sheep, immunoreactive $\mathrm{GnRH}$ is present in the hypothalamic neurones at about day 43 of gestation (Caldani, 1986), and immunodetectable concentrations of $\mathrm{GnRH}$ have been reported on day 60 of gestation (Gluckman, 1981). Immunoreactive GnRH has been found in perikarya situated in the medial preoptic area of 60-day-old fetuses, but not in the nerve terminals of the median eminence (Polkowska, 1986). The stores of immunoreactive GnRH are present in the median eminence from day 75 of gestation (Fig. IC), but only in very small amounts and there is no change up to term (day I47) (Polkowska, 1986). The GnRH neuronal centres in the fetus are localized at the same sites of the brain as in adult sheep, i.e. diagonal band of Broca along the midline, in the medial preoptic area at the level of the organum vasculosum of the lamina terminalis, in lateral parts of the anterior hypothalamic area and, rarely, in the medial basal hypothalamus (Polkowska, 1986; Wood et al., 1992). Development of $\mathrm{GnRH}$ neurones seems to be complete by day 85 of gestation. The total number of GnRH perikarya, number of neuronal processes and the pattern of distribution are equivalent to those of adult females and do not differ between the sexes (Wood et al., 1992).

Circulating concentrations of LH and FSH in sheep fetuses come from the fetal pituitary gland (Foster et al., 1972). Immunoreactive $\mathrm{LH}$ producing cells are detectable by immunocytochemical techniques as early as day 49 (Messaoud-Toumi et al., 1993a). Their number increases in both sexes between day 100 and day 120 of gestation and remains high until term. Cells containing FSH are found from about day 90 and their percentage increases by about twice between day 120 and day 130 and then appears to fall at day 140 (Messaoud-Toumi et al, 1993a). LH and FSH has been detected in blood plasma by radioimmunoassay as early as day 58 of gestation (Sklar et al,, 1981). The plasma concentrations of LH and FSH increase from low values at days 55-60 to a maximum at about day 120 of gestation followed by a fall to a low concentration at term (Foster et al. 1972). Both gonadotrophins are secreted in a pulsatile fashion (Sklar ef al., 198I; Clark et al., 1984; Albers ef al, 1993). The fetal pituitary gland can respond to $\mathrm{GnRH}$ and the amount of LH released by $\mathrm{GnRH}$ injections increases after day 84 of gestation to reach a peak at day 115-132 of fetal life before decreasing in late gestation (Mueller et al., 1981). The changes in plasma concentration of gonadotrophins and increase in the sensitivity of gonadotrophic cells to $\mathrm{GnRH}$ in the fetus reflect the activation and maturation of the hypothalamic systems that regulate gonadotrophin secretion. Moreover, it has been suggested that endocrine feedback exerted by fetal gonads also develops in late gestation (reviewed by Messaoud-Toumi et al., 1993b).

\section{Growth}

Postnatal development of the hypothalamo-pituitary-gonadotrophic axis from infancy to the prepubertal period has been poorly described in sheep. Except for the circulation of gonadotrophins, which can reflect changes in the function of the hypothalamo-pituitary-gonadotrophic axis, very little is known about the development of the GnRH neuronal system, the pituitary gonadotrophs or the regulatory interactions between $\mathrm{GnRH}$ and the gonadotrophs at this developmental stage. Maturational changes drive the transition from the infantile to prepubertal activity and lead to sexual maturation. The 

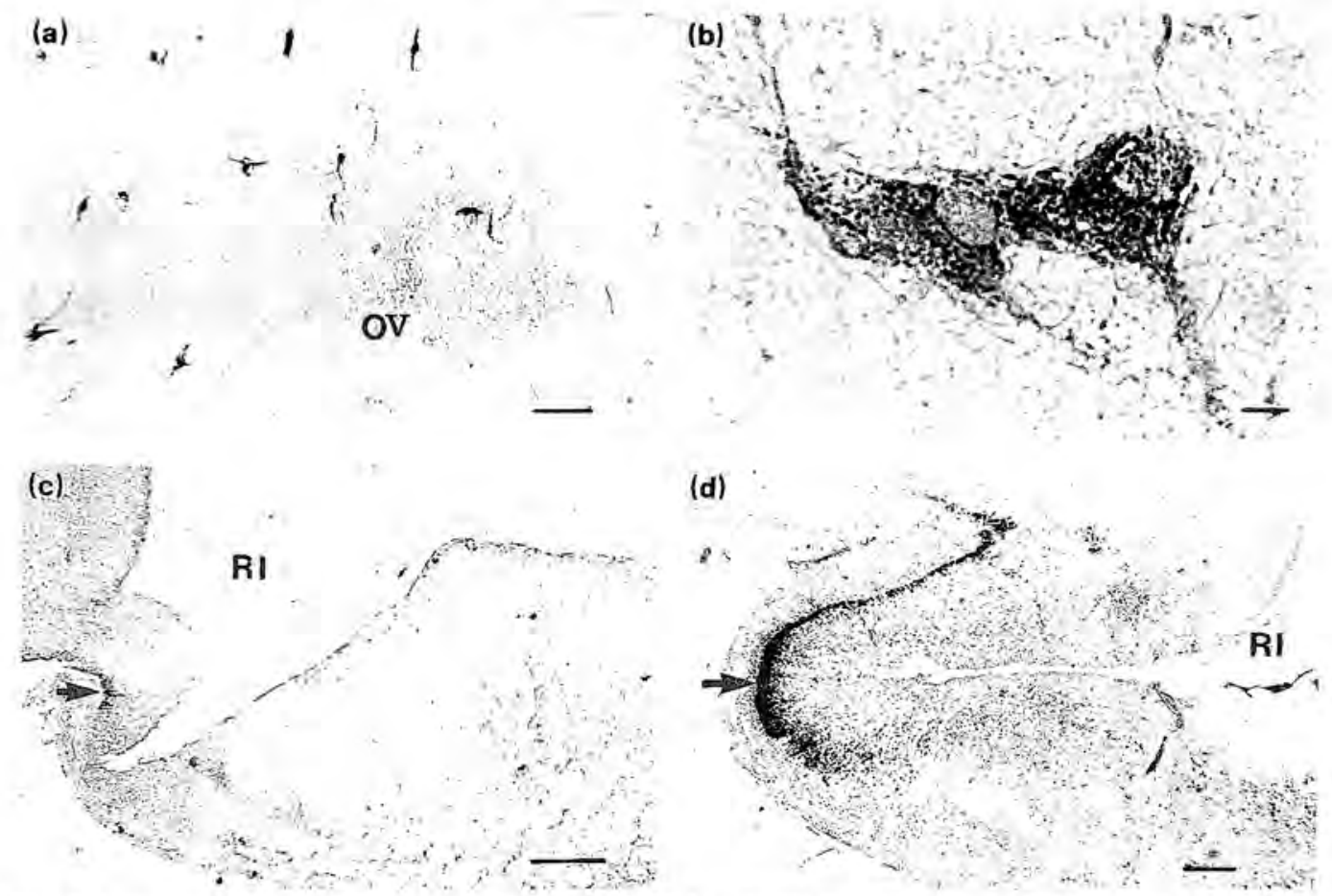

Fig. 1, Immunoreactive GnRH neuronal system in pre-and postnatal sheep. (a) The GnRH neuronal centre in the medial preoptic area of a 14-week-old lamb. Scale bar represents $200 \mu \mathrm{m}$. (b) Higher magnification of immunoreactive $\mathrm{GnRH}$ perikarya. Scale bar represents $25 \mu \mathrm{m}$. (c) and (d) Immunoreactive $\mathrm{GnRH}$ (arrows) in the nerve terminals of the central part of the median eminence of (c) a 120-day-old fetus and (d) I4-week-old lamb, Scale bar represents $100 \mu \mathrm{m}$ (c) and $200 \mu \mathrm{m}$ (d). OV: organum vasculosum of the lamina terminalis; RI: recessus infundibularis. Adapted from Polkowska (1986) with permission from Folia Histochemica Cytobiologica and Polkowska et al. (1987) with permission from Reproduction, Nutrition Developpement.

endocrine changes in this period that lead to the onset of puberty are not sudden but are the result of progressive development beginning after the birth of the animal.

Although GnRH neuronal centres seem to be established in sheep fetuses during late gestation (Wood ef al., 1992), our data obtained from growing females from their early postnatal days until 16 weeks of age reveal an intensification of hypothalamic $\mathrm{GnRH}$ immunoreactivity that is manifested by more immunoreactive $\mathrm{GnRH}$ perikarya and increased immunoreactive $\mathrm{GnRH}$ stores in the median eminence (Polkowska et al. 1987). These observations can be interpreted as reflecting an increase in the secretory activity of neurones producing GnRH. The storage of the hormone in the nerve terminals of the median eminence reaches a maximum at about 12 weeks of age and remains at that level until at least week 16 (Fig. 1d) (Polkowska et al., 1987). No differences in the organization of the GnRH neuronal system has been noticed between adult and 12-week-old female lambs (Caldani et al., 1988), indicating that there is no reorganization of the $\mathrm{GnRH}$ neuronal system during postnatal development. The $\mathrm{GnRH}$ neuronal centres have been localized in the same region, between the septo-preoptic area (Fig. Ia, b) and the medial basal hypothalamus in fetal, growing and adult sheep of both sexes (Lehman et al., 1986; Polkowska, 1986; Polkowska et al., 1987; Caldani et al., 1988). Development of the GnRH neuronal system has been investigated more precisely in other species. In growing rats and rabbits, age-related transformation of the subtypes of $\mathrm{GnRH}$ perikarya and increased frequency of some subtypes has been observed (Wray and Hoffman, 1986; Yellon and Newman, 1991). It seems that a more detailed analysis of the morphology of the GnRH neuronal system in sheep might lead to a better understanding of the developmental processes leading to sexual maturation. 
Except for the neonatal period, the postnatal development of gonadotrophs in the sheep pituitary gland has not been well described. Generally, the number of all types of gonadotrophs (LH, FSH and $\mathrm{LH} / \mathrm{FSH}$ ) increases in newborn lambs by about two times in comparison with those of the fetus. In females only, the number of LH/FSH cells does not change after birth (Messaoud-Toumi et al., 1993a). Activation of the hypothalamo-pituitary-gonadotrophic axis during postnatal growth should be reflected in changes in gonadotrophin concentrations in plasma. Concentrations of LH vary in a manner dependent on sex. In male lambs the mean concentrations of LH increases progressively during the first 10 weeks after birth (Cotta et al, 1975), reflecting an increase in the frequency of the pulsatile discharges. The pulses are initiated shortly after birth and their frequency increases by about 20 times up to 8 weeks of age (Foster et al., 1978). In female lambs the mean serum concentrations of LH are lower during the first 8 weeks of life than in anoestrous adults (Foster et al., 1975a). By I1 weeks of age, circulating LH concentrations increase to values two to five times greater than those observed in adults and stay at this level until the first oestrous cycle (Foster et al., 1975b). This increase reflects the onset of pulsatile LH release, but the patterns display only the tonic and not the phasic mode of secretion (Foster et al, 1975a). Other reports define the circulating LH in plasma of 18-24-week-old females as generally low, with very infrequent pulses until the week before the first ovulation (Huffman et al., 1987; I'Anson and Legan, 1988). Circulating concentrations of FSH in plasma of females are low up to 8 weeks of life; they then increase and by II weeks attain the concentrations found in adults and remain stable until the preovulatory phase of the oestrous cycle (Foster et al, 1975b). According to these authors, the differences between the patterns of circulating LH and FSH in growing female lambs support the concept of different mechanisms for regulating tonic secretion of the two gonadotrophins. After the loss of pituitary response to GnRH during late gestation (Mueller et al., 1981), the responsiveness to exogenous $\mathrm{GnRH}$ increases with age (Foster et al, 1972; Mueller ef al., 1981). The responsiveness increases progressively in both male and female lambs up to 3 weeks of age (Mueller et al, 1981) and continues to increase in males after 12 weeks of age (Galloway and Pelletier, 1974). The rate of this change depends not only on sex and age but also on breed (Haley et al., 1989). There are no reports providing direct evidence of the pulsatile secretion of $\mathrm{GnRH}$ during the growing period of sheep, as there is for adult ovariectomized ewes, cyclic ewes and rams (Clarke and Cummins, 1982; Caraty and Locatelli, 1988; Moenter ef al., 1991). Coincidental increases in the pulsatile release of both GnRH and LH have been established in bull calves between 8 and 12 weeks of age, using the hypophyseal portal blood sampling technique, A pulsatile pattern of GnRH release was present by 2 weeks of age and increased linearly through to 12 weeks of age (Rodriguez and Wise, 1989). It is likely that the pattern of maturation of the hypothalamo-pituitary-gonadotrophic axis in sheep is parallel to that in calves.

\section{Conclusions}

The hypothalamo-pituitary-gonadotrophic axis of the sheep fetus matures from midgestation until late gestation. The existence of central regulatory mechanisms is supported by the presence of $\mathrm{GnRH}$ in the fetal brain and its localization in structures typical of the adult brain, by the morphological evidence of activity in the gonadotrophs, by their increasing sensitivity to $\mathrm{GnRH}$, and finally by changes in the secretory profiles of gonadotrophins and their pulsatile mode of release. It appears that this central control mechanism develops in parallel with changes in morphology.

The morphological evidence, based on immunocytochemical studies of the GnRH neuronal system together with age-dependent changes in the pattern of gonadotrophin secretion and sensitivity of the gonadotrophs to GnRH, suggests that during the growing period the central mechanisms governing gonadotrophin secretion mature progressively and are established during the first 12 weeks of age.

\section{Hypothalamo-Pituitary-Somatotrophic Axis}

\section{Prenatal period}

Growth hormone $(\mathrm{GH})$ is one of the most important factors controlling the growth of animals, although its role in the fetus is not clear (Gluckman, 1986). It is well established that pulsatile GH release 
(a)

(d)

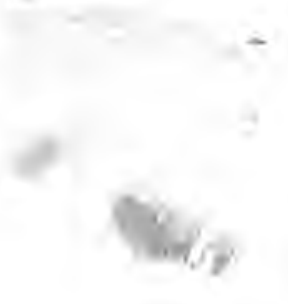

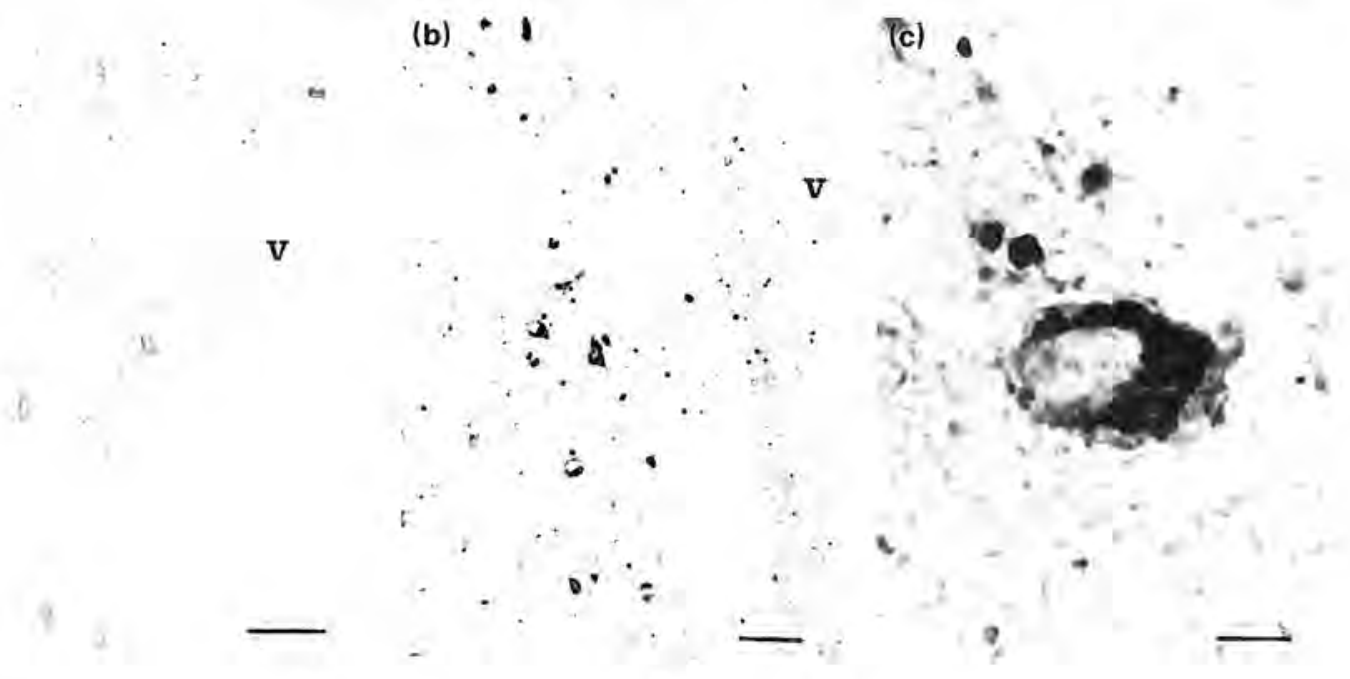

RI

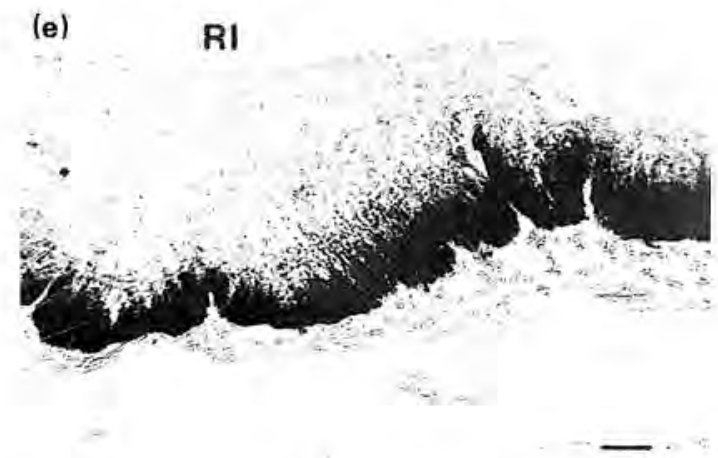

Fig. 2. Immunoreactive somatostatin neuronal system in pre- and postnatal sheep. (a) and (b) Immunoreactive somatostatin neuronal centre in the periventricular nudeus of (a) 135-day-old fetus and (b) 14-week-old lamb. Scale bars represent $100 \mu \mathrm{m}$. (c) Higher magnification of the immunoreactive somatostatin perikarion. Scale bar represents $10 \mu \mathrm{m}$. (d) and (e) immunoreactive somatostatin in the nerve terminals of the central part of the median eminence of (d) 120-day-old fetus, and (e) 14-week-old lamb. Scale bar represents $100 \mu \mathrm{m}$ (d) and $200 \mu \mathrm{m}$ (e). RI: recessus infundibularis; V: third ventricle of the brain. Adapted from Polkowska 1986, with permission from Folia Histochemica Cytobiologica and Polkowska et al., 1987, with permission from Reproduction, Nutrition Developpement.

is influenced by a balance between inhibitory and stimulatory action of two hypothalamic hormones: somatostatin and growth-hormone-releasing hormone (GHRH) (Tannenbaum and Ling, 1984). Both hormones are present in the hypothalamus of sheep fetuses at least by midgestation (reviewed by De Zeghner et al., 1989), but only the somatostatin neuronal system has been detected directly in the fetal brain by immunocytochemistry (Polkowska, 1986). GHRH neurones have not been detected in the brain of either fetal, growing or adult sheep.

Immunoreactive somatostatin has been found as early as day 60 of gestation (the earliest stage investigated) in perikarya forming prominent centres in the ventromedial hypothalamic nucleus and lateral preoptic nucleus. Dispersed perikarya are also distributed in extrahypothalamic areas mainly in the amygdala, lateral septum, olfactory tubercles and nucleus accumbens. As the fetus becomes older, the centre in the ventromedial nucleus gradually disappears and, from day 105 of gestation, some individual immunoreactive somatostatin perikarya are found in the rostral periventricular region of the hypothalamus (Fig, 2a). This new centre does not attain the characteristic pattern of adult sheep. The immunoreactive somatostatin is found in the nerve terminals of the median eminence as early as day 75 of gestation and the stores gradually increase up to term (Fig. 2d) (Polkowska, 1986). This reorganization 
of the somatostatin neuronal centres during fetal growth may be related to other non-hormonal functions of somatostatin in early gestation.

Growth hormone is first detectable in pituitary cells of sheep fetuses by immunofluorescence between day 43 and day 53 (Stokes and Boda, 1968). The concentration of GH in the blood plasma of the fetus is about 20 times higher than that seen in adults (Basset and Gluckman, 1986). A triphasic pattern of $\mathrm{GH}$ secretion has been demonstrated in the fetus; high concentrations are found at midgestation (days 60-70), followed by a fall at days 100-110 and an increase during late gestation (days 130-140) (Gluckman et al, 1979a). GH release is pulsatile in the fetus (Basset and Gluckman, 1986) and this pattern is well established by the end of gestation (Albers et al.; 1993). As yet, there is no direct evidence for spontaneous release of somatostatin or GHRH from the hypothalamus, but both of these hypothalamic factors play a role in the control of fetal $\mathrm{GH}$ secretion, as lesion of fetal median eminence induces a fall in $\mathrm{GH}$ secretion and abolishes pulsatile $\mathrm{GH}$ release (Gluckman and Parsons, 1985). Experiments in vitro and in vivo have shown that GHRH is active as early as day 70 of gestation (Blanchard et al., 1988). The response of pituitary cells to GHRH stimulation in vitro is not related to the age of the fetus (Blanchard et al., 1988) but, in vivo, this response is higher in 90-120-day-old fetuses than in 127-145-day-old fetuses or in neonates (De Zeghner et al., 1989). The regulatory role of somatostatin during fetal development seems to be more complex. Administration of somatostatin results in a decrease in basal $\mathrm{GH}$ concentrations and somatostatin withdrawal elicits a rise in $\mathrm{GH}$ concentrations in the sheep fetus and in the neonate (Gluckman et al, 1979b). However, GH release is much less sensitive to the inhibitory effects of somatostatin in the fetus than in the neonate (Gluckman, 1984). In vitro, somatostatin decreases GHRH-induced secretion in fetal somatotrophs more than in neonatal cells (Silverman ef al, 1989). In vivo, administration of somatostatin has no effect on the GH response to GHRH in fetuses from day 115 of gestation, but near term this response gradually increases (De Zeghner et al., 1989).

\section{Neonatal and growing period}

Studies of the immunoreactive somatostatin neuronal system have demonstrated two different somatostatin centres in the forebrain of growing lambs. One centre develops in the rostral periventricular band of the paraventricular and suprachiasmatic nuclei, and the other develops in the preoptico-septal area (Polkowska et al., 1987). Perikarya have not been found in the ventromedial hypothalamic nucleus of lambs, as is characteristic for the fetal period. The number of periventricular perikarya increases with age of the lamb; it is moderate in neonates and highest in the hypothalami of 14-week-old sheep (Fig. 2b, c). The immunoreactive somatostatin perikarya situated in the preoptico-septal area differ in morphology from those in the periventricular region, and their number declines after 10 weeks of age. In the nerve terminals of the central part of the median eminence and infundibulum, immunoreactive somatostatin is abundant up to 10 weeks of age except during the first few days after birth (Fig. 2e). Between 10 and 16 weeks of age, the depletion of stored somatostatin becomes evident. Data from other species show that the somatostatin neurones from the periventricular centre project mainly to the median eminence and are involved in regulation of pituitary GH cells (reviewed by Polkowska ef al., 1987). Somatostatin from the preoptico-septal area is independent of the hypothalamic system and does not play a hypophysiotrophic function (Krisch, 1980). The reduction of the somatostatin stores in the median eminence during the early postnatal period may be caused by a rapid release of this hormone into the capillary system of the primary plexus (Polkowska et al,, 1978), an interpretation that is consistent with changes in $\mathrm{GH}$ plasma concentrations during the perinatal period.

The high plasma GH concentrations in the fetus decrease rapidly. I h after birth and reach low values in comparison with those seen in adults (Basset and Gluckman, 1986). GH secretion in neonatal lambs is much more sensitive to the inhibitory effects of somatostatin than it is in the fetus (Gluckman, 1984). Moreover, the suppressive effect of somatostatin on the GH response to GHRH increases sharply at birth (De Zeghner et al., 1989), suggesting that somatostatin is involved in the fall in plasma GH concentrations around the neonatal period in sheep.

Little is known about the maturation of the central regulatory system during growth in lambs. It is evident from the morphological studies that the somatostatin neuronal system is mature by $8-10$ 
weeks of age (Polkowska et al., 1987). The depletion of somatostatin stores in the median eminence from 10 to 16 weeks of age, interpreted as being due to augmented release, presumably reflects further maturation of the $\mathrm{GH}$ secretory mechanism. Circulating $\mathrm{GH}$ concentrations in growing lambs rise after birth and then tend to decline with age and remain at values similar to those seen in adults (Klindt et al, 1985). Immunization of lambs against somatostatin at 27-103 days of age removes the inhibitory effect of somatostatin and increases growth by augmentation of GH secretion (Spencer et al, 1983).

\section{Conclusions}

The central regulation of $\mathrm{GH}$ secretion in the sheep fetus probably has the dual control characteristic of adults but it seems to be relatively immature. The secretion of $\mathrm{GH}$ is very high in this period compared with that in adults, and seems to be under the stimulatory influence of GHRH, but not the inhibitory effect of somatostatin. This can be explained by the immaturity of the hypothalamic somatotrophin neuronal system and by pituitary insensitivity to somatostatin. However, the early presence of somatostatin within the brain of the developing embryo and its topographical heterogeneity suggest an additional role for this peptide that may be different from its usually presumed hormonal or neurotransmitter function.

In growing sheep, establishment of the somatostatin hypophysiotrophic neuronal centre together with stabilization of $\mathrm{GH}$ secretion at a level similar to that in adults presumably reflect further maturation of the GH secretory mechanism. It is suggested that the importance of somatostatin as a hypophysiotrophic hormone controlling lamb growth increases with age and that this system matures after birth.

\section{Interactions between Gonadotrophic and Somatotrophic Axes}

The presented data suggest that the ontogenic development of the gonadotrophic axis and somatotrophic axis is independent in sheep. Some of the unanswered questions involve the possible associations between the systems. Do they interact with each other during the developmental period? Is there direct interaction? There are some positive physiological manifestations implying such interaction. For instance, the sexually dimorphic pattern of GH secretion, the interrelationship between body size and onset of puberty, the link between food intake, growth and $\mathrm{GnRH}$ secretion. The majority of proposed mechanisms for these processes are considered at the level of the central nervous system. It has been found that $\mathrm{GH}$ is not directly involved in the developmental pattern of $\mathrm{LH}$ release in growing lambs (Suttie ef al., 1991). There is no evidence for the existence of direct synaptic connections between the $\mathrm{GnRH}$ and GHRH or somatostatin neurones; the communication may be mediated by substances synthesized in the brain or by other bloodborne signals. One of the proposed cues that can link the gonadotrophic and somatotrophic systems are the sex steroids. In ruminants, plasma GH concentration is generally enhanced by gonadal steroids, probably at the pituitary (reviewed by Breier and Gluckman, 1991). In neonatal rats, steroids play an important role in the hypothalamus by modulating the number; sensitivity to sex steroids and gene expression of the somatostatin and GHRH neurones (Chowen et al., 1993). However, the sex steroids exert their feedback control on gonadotrophin secretion during fetal and postnatal development (Foster et al., 1975a; Huthaniemi and Warren, 1990). Another proposed candidate for mediating growth and reproduction is neuropeptide $Y$, a strong modulator of feed intake in ruminants at the paraventricular nucleus (reviewed by Miner, 1992). The axons containing neuropeptide $Y$ synapse on GnRH and somatostatin neurones (reviewed by Halasz, 1993). The somatostatin may influence the somatic growth by controlling $\mathrm{GH}$ release as well as by controlling ingestion (Borer $e$ t al., 1983). The contributions of neuropeptide $Y$ to the regulation of neurosecretion of GnRH neurones in lambs was described for example by Ober and Malven (1992) and stimulation of GH in rats by McDonald et al. (1985). Other possible mediators that can link growth and reproduction are extensively examined in the models of underfed, growth retarded animals. In general, the development of gonadotrophic and somatotrophic regulatory systems during prenatal and postnatal periods seems to be rather complex. 


\section{General conclusion}

In sheep the ontogenic development of the hypothalamo-pituitary axis regulating secretion of gonadotrophins and somatotrophin seems to be independent. The changes in morphology and the changes in the secretory activity of the hypothalamic centres and pituitary cells begin at the midgestation period of fetal life. The adult pattern of the central regulatory mechanism governing the secretion of gonadotrophins seems to be completed during the second part of gestation. In contrast, the regulatory system of growth hormone secretion is relatively immature until the first weeks of postnatal life.

\section{References}

Albers N, Bettendorf M, Herrman M, Kaplan SL and Grumbach MM (1993) Hormone ontogeny in the ovine fetus. XXVII. Pulsatile and copulsatile seretion of luteinizing hormone. follicle stimulating hormone, growth hormone and prolactin in late gestation: a new method for the analysis of copulsatility Endocrinology 132 701-709

Basset NS and Gluckman.PD (1986) Pulsatile growth hormone secretion in the ovine fetus and neonatal lamb joumal of Endocrinology 109 307-312

Blanchard MM, Goodyer CG, Charrier J and Berenton B (1988) In vitro regulation of growth hormone $(\mathrm{GH})$ release from ovine pituitary cells during fetal and neonatal development: effects of $\mathrm{GH}$-releasing factor, somatostatin, and insulin-like growth factor I Endacrinology 122 2114-2120

Borer KT, Shapiro B and Vinik AI (1983) A role for somatostatin in the control of hamster growth Brain Research Bullefin 11 663-669

Breier BH and Gluckman PD (1991) The regulation of postnatal growth: nutritional influences on endocrine pathways and function of the somatotrophic axis Livestock Production Science 27 77-94

Caldani M (1986) Mise en evidence immunohistochimique des hormones a LHRH du monton (Ovis aries). Systematisation et ontogenese Thesis, Universite de Paris-VI

Caldani M, Batailler M, Thiery JC and Dubois MP (1988) LHRHimmunoreactive structures in the sheep brain Hisfochemistry 89 129-139

Caraty A and Locatelli A (1988) Effect of time after castration on secretion of LHRH in the ram Joumal of Reproduction and Ferfility 82, 263-269

Chowen JA, Argente J, Gonzalez-Parra S and Garcia-Segura LM (1993) Differential effects of the neonatal and actult sex steroid environments on the organization and activation of hypothalamic growth hormone-releasing hormone and somatostation neurons Endocrinology 133 2792-2802

Clark SJ, Ellis N, Styne DM, Gluckman PD, Kaplan SL and Grumbach MM (1984) Hormone ontogeny in the ovine fetus. XVII. Demonstration of pulsatile luteinizing hormone secretion by the fetal pituitary gland Endocrinology 115 1774-1779

Clarke IJ and Cummins IT (1982) The temporal relationship between gonadotropin releasing hormone $(\mathrm{GnRH})$ and luteinizing hormone $(\mathrm{LH})$ secretion in ovariectomized ewes Endocrinelogy 111 1737-1739

Cotta Y, Terqui M, Pelletier J and Courot M (1975) Testosterone et $\mathrm{LH}$ plasmatiques chez lagneau de la naissance a la puberte Compres Rendus Academic des Science Paris (D) 280 1473-1476
De Zeghner F, Daaboul J Grumbach MM and Kaplan SL (1989) Hormone ontogeny in the ovine fetus and neonate. XXII. The effect of somatostatin on the growth hormone (GH) response to GH-releasing factor Endocrinology 124 III4-III7

Foster DL, Roach JE, Karsch FJ, Norton HW, Cook B and Nalbandov AV (1972) Regulation of luteinizing hormone in the fetal and neonatal lamb. I. LH concentrations in blood and pituitary Endocrinology 90 102-111

Foster DL, Jaffe RB and Niswender GD (1975a) Sequential patterns of circulating $\mathrm{LH}$ and FSH in female sheep during the early postmatal period: effect of gonadectomy Endacrinology 96 15-21

Foster DL, Lemons JA, Jaffe RB and Niswender GD (1975b) Sequential patterns of circulating luteinizing hormone in female sheep from early postnatal lite through the first estrous cycles Endocrinology $97985-993$

Foster DL, Mickelson IH, Ryan KD, Coon GA, Drongowski RA and Holt IA (1978) Ontogeny of pulsatile luteinizing hormone and testosterone secretion in male lambs Endocrinology $102 \quad 1137-1146$

Galloway DG and Pelletier I (1974) Influence of age on the pituitary response of male lambs to synthetic $\mathrm{LH}-\mathrm{RH}$ injection Hormone Metabolism 6 24 $1-246$

Gluckman PD (1981) Maturation of hypothalamic-pituitary function in the ovine fetus and neonate. The fetus and independent life Ciba Foundation Symposium 86 5-42

Gluckman PD (1984) Neuroendocrine function in the ovine fetus: studies in the regulation of growth hormone and prolactin secretion In Fetal Neuroendocrimology pp 193-207 Eds P Ellendorf, P Gluckman and N Parvizi. Perinotology Press, Ithaca

Gluckman PD (1986) The role of pituitary hormones, growth factors and insulin in the regulation of fetal growth Oxford Reviews of Reproductive Biology 18 1-59

Gluckman PD and Parsons J (1985) Growth hormone secretion in the fetal sheep following stereotaxic electrolylic lesioning of the fetal hypothalamus Joumal of Developmential Physiology 7 25-30

Gluckman PD, Mueller PL, Kaplan SL, Rundolph AM and Grumbach MM (1979a) Hormone ontogeny in the ovine fetus. I. Circulating growth hormone in mid and late gestation Endocrinology $104 \quad 162-168$

Gluckman PD, Mueller PL, Kaplan SL and Grumbach MM (1979b) Hormone ontogeny in the ovine fetus. III. The effect an exogenous somatostatin Endocrinology 104 974-978

Halasz B (1993) Neuroendocrinology in 1992 Neuroendocrinology $57 \quad 1196-1207$ 
Haley CS, Lee GJ, Fordyce M, Baxter G, Land RB and Webb R (1989) Study of LH response to GnRH in the young male as a criterion of genetic merit for female reproduction in sheep Journal of Reproduction and Fertility 86 119-133

Huffman LJ, Inskeep EK and Goodman RL (1987) Changes in episodic luteinizing hormone secretion leading to puberty in the lamb Biology of Reproduction 37 755-761

Huthaniemi IT and Warren DW (1990) Ontogeny of pituitarygonadal interactions: current advances and controversies Trends in Endocrine Metabolism 1 356-362

I'Anson H and Legan SJ (1988) Does the first LH surge of the breeding season initial the first full length cycle in the ewe Joumal Reproduction and Ferfility 82 761-767

Klindt J, Ohlson DL, Davis SL. and Schanbacher BD (1985) Ontogeny of growth hormone, prolactin, luteinizing hormone and testosterone secretory pattern in the ram Biology of Reproduction 33 436-445

Krisch B (1978) Hypothalamic and extrahypothalarric distribution of somatostatin immunoreactive elements in the rat brain Cell and Tissue Research 195.499-513

Lauder JM (1983) Hormonal and humoral influences on the brain development Psychoneuroendocrinology 8 121-155

Lehman MN, Robinson JE, Karsch FJ and Silverman BL (1986) Immunocytochemical localization of luteinizing hormonereleasing hormone (LHRH) pathways in the sheep brain during anestrus and mid-luteal phase of the estrous cycle Journal of Comparative Neturology 244 19-35

McDonald JK, Lumpkin MD, Samson WK and McCann SM (1985) Neuropeptide $Y$ affects secretion of luteinizing hormone and growth hormone in ovariectomized rats Proceedings of the National Academy of Sciences USA $\mathbf{8 2}$ $561-564$

Matwijiw J, Thliveris JA and Faiman C (1989) Hypothalamopituitary portal development in the ovine fetus Biology of Reproduction $401127-1130$

Messaoud-Toumi LH, Taragnat C and Durand P (1993a) Heterogeneity in the storage of gonadotropins in the ovine fetus and evidence for luteinizing hormone-follicle stimulating hormone cells in the fetal pituitary Bjology of Reproduction $481239-1245$

Messaoud-Toumi LH, Taragnat C and Durand P (19936) Castration effects on the gonadotrope cell populations of the fetal sheep pituitary in late gestation Neuroendocrinology $\mathbf{5 8}$ $548-554$

Miner IL (1992) Recent advances in the central control of intake in ruminants Journal of Animal Sciences $\mathbf{7 0}$ $1283-1289$

Moenter SM, Caraty A, Locatelli A and Karsch FJ (1991) Pattern of gonadotropin-releasing hormone ( $\mathrm{GnRH}$ ) secretion leading up to ovulation in the ewe: existence of a preovulatory GnRH surge Endocrinology 129 1175-1182

Mueller PL, Sklar CA, Gluckman PD, Kaplan SL and Grumbach MM (1981) Hormone ontogeny in the ovine fetus. IX. Luteinizing hormone and follicle-stimulating hormone response to luteinizing hormone-relating factor in mid and late gestation and in the neonate Endocrinology $108881-886$
Ober JA and Malven PV (1992) Effect of growth retardation on pituitary lutejnizing hormone and hypothalamic neuropeptide $Y$ in ovariectomized sheep Neuroendocinology 56 331-339

Ojeda S, Andrews W, Advis J and White S (1980) Recent advances in the endocrinology of puberty Endocrine Reviews 1 228-257

Polkowska J (1986) Ontogeny of luteinizing hormonereleasing hormone (LHRH) and somatostatin (SRIH) in the hypothalamus of the sheep Folia Histocliemica Cytobiologica 24 195-199

Polkowska J. Dubois MP and Jutisz M (1987) Maturation of luteinizing hormone-releasing hormone (LHRH) and somatostatin (SRIF) neuronal systems in the hypothalamus of growing ewe lambs Reproduction. Nutrition Developpemenl $27627-639$

Rodriguez RE and Wise ME (1989). Ontogeny of pulsatile secretion of gonadotropin-releasing hormone in the bull calf during infantile and pubertal development Endocrinology $124 \quad 248-256$

Silverman BL, Bettendorf M, Kaplan SL, Grumbach MM and Miller WL (1989) Regulation of growth hormone (GH) secretion by $\mathrm{GH}$-releasing factor, somatostatin and insulinlike growth factor $I$ in ovine fetal and neonatal pituitary cell in vitro Endocrinology $124 \quad 84-89$

Sklar CA, Mueller PL, Gluckman PD, Kaplan SL, Rudolph AM and Grumbach MM (1981) Hormone ontogeny in the ovine fetus. VII. Circulating luteinizing hormone and follicle-stimulating hormone in mid and late gestation Endocrinology 108 874-880

Spencer GSG, Garssen GJ and Hart IE (1983) A novel approach to growth promotion using auto-immunization against somatostatin. I. Effects of growth and hormone levels in lambs Livestock Production Science 10 25-37

Stokes M and Boda JM (1968) Immunofluorescent localization of growth hormone and prolactin in the adenohypophysis of fetal sheep Endocrinology 83 1362-1364

Suttie JM, Kostyo JL, Ebling FJP, Wood R, Bucholtz DC, Skottner A, Adel TE, Towns RJ and Foster DL (1991) Metabolic interfaces between growth and reproduction. IV. Chronic pulsatile administration of growth hormone and the timing of puberty in the female sheep Endocrinology $1292024-2032$

Tannenbaum GS and Ling N (1984) The interrelationship in generation of the ultradian rhythm of $\mathrm{GH}$ secretion Endocrinology 115 1952-1957

Wood RJ, Newman SW. Lehman MN and Foster DL (1992) $\mathrm{GnRH}$ neurons in the fetal lamb hypothalamus are similar in males and females Neuroendocrinology $55 \quad 427-433$

Wray S and Hoffman G (1986) Postnatal morphological changes in rat LHRH neurons correlated with sexual maturation Neuroendocrinology $43 \quad 93-97$

Yellon SM and Newman SW (1991) A developmental study of the gonadotropin-releasing hormone neuronal system during sexual maturation in the male Djungarian hamster Biology of Reproduction $45 \quad 440-446$ 